\title{
Implementasi Pelatihan Edmodo di SMP Muhammadiyah 1 \\ Kota Malang
}

\author{
M. Mansur ${ }^{1}$, Rose Fitria Lutfiana ${ }^{2}$ \\ 1,2,FKIP Universitas Muhammadiyah Malang \\ e-mail: ${ }^{1}$ mansur@umm.ac.id, ${ }^{2}$ rose@umm.ac.id
}

\begin{abstract}
One of the challenges of the industrial revolution era 4.0 in the field of education is ini line with the $21^{\text {st }}$ century teacher's professional competence, which is related to the ability of teachers to be able to implement e-learning in teaching and learning in classroom. Junior High School of Muhammadiyah 1 Malang was chosen as a place community service because the implementation of the learning system with e-learning was still constrained by human resources (teachers) who did not understand what e-learning was. The training and mentoring activities are carried out through four stages namely focus group discussions (FGD), training, mentoring and evaluation monitoring. The results of community service activities included: almost $78,2 \%$ of teachers who participated in training and assistance in using e-learning have been able to master the implementation of e-learning in the teaching and learning process and $65,2 \%$ of teachers who participated in community service activities have been implementing e-learning in odd semester 2019/2020.
\end{abstract}

Keywords: e-learning, teacher, training

Abstrak. Salah satu tantangan era revolusi industri 4.0 di bidang pendidikan sejalan dengan kompetensi profesional guru abad 21, yaitu terkait dengan kemampuan guru untuk bisa mengimplementasikan e-learningdalam proses belajar mengajar di Kelas.SMP Muhammadiyah 1 Kota Malang dipilih sebagai tempat pengabdian kepada masyarakat karena dalam pengimplementasian sistem pembelajaran dengan e-learningmasih terkendala pada sumber daya manusia (guru) yang belum memahami apa itu e-learning. Kegiatan pelatihan dan pendampingan ini dilakukan melalui empat tahapan yaitu focus group discussion (FGD), pelatihan, pendampingan dan monitoring evaluasi. Hasil dari kegiatan pengabdian kepada masyarakat ini antara lain: hampir $78,2 \%$ guru yang mengikuti pelatihan dan pendampingan penggunaan e-learningtelah mampu mengguasai implementasi $e$ learningdalam proses belajar mengajar dan $65,2 \%$ guru yang mengikuti kegiatan pengabdian kepada masyarakat ini telah mengimplementasikan e-learningpada pembelajaran semester ganjil 2019/2020.

Kata kunci: e-learning, guru, pelatihan

\section{Pendahuluan}

Revolusi Industri 4.0 ditandai oleh munculnya Internet of Things (IoT), big data, artificial intellegence, cloud computing, block chain dan sebagainya. Imbas dari revolusiindustry 4.0 tidak hanya merambah pada bidang-bidang tertentu, seperti ekonomi, sosial, budaya saja tetapi hampir di semua bidang termasuk pendidikan. Dalam bidang pendidikan dampak 18 | Implementasi Pelatihan Edmodo... 
adanya revolusi industri 4.0 salah satunya ditandai dengan adanya inovasi pembelajaran dengan memanfaatkan informasi digital dengan tujuan meningkatkan mutu pembelajaran (Pervical dan Ellington dalam Syamsuar dan Reflianto, 2018).

Dalam dunia pendidikan sendiri adanya revolusi industri 4.0 membawa tantangan tersendiri seperti kompetensi guru yang dituntut untuk menguasai inovasi pembelajaran yang berhubungan dengan teknologi informasi. Sebagai seorang pendidik yang profesional yang mempunyai tugas utama untuk mendidik, mengajar, membimbing, mengarahkan, melatih, menilai serta mengevaluasi peserta didiknya, guru juga mempunyai kewajiban lain terkait peningkatan dan pengembangan kualifikasi akademik, serta kompetensi secara berkelanjutan. Secara yuridis formal hal itu dipertegas dalam Undang-undang No 14 Tahun 2005 tentang Guru dan Dosen, yaitu guru profesional harus memiliki empat kompetensi diantaranya kompetensi pedagogi, kompetensi kepribadian, kompetensi sosial dan kompetensi profesional. Maka sangat penting sekali guru harus memiliki kompetensikompetensi tersebut, karena jika guru tidak kompeten maka menjadi mustahil menerapkan inovasi pembelajaran berbasis teknologi informasi.

Sejalan dengan empat kompetensi guru profesional yang diatur dalam Undangundang No 14 Tahun 2005 Tentang Guru dan Dosen, Qusthalani (dalam Wahyuni, 2018) menyatakan bahwa terdapat lima kompetensi yang harus dimiliki oleh guru di era revolusi industri 4.0 antara lain: (a) educational competence, yaitu kompetensi pembelajaran berbasis internet sebagai basic skill; (b) competence for technological commercialization, yaitu kompetensi guru yang berkaitan dengan kemampuan guru untuk membawa peserta didik memiliki sikap enterpreneurship dengan teknologi atas hasil karya inovasi peserta didik; (c) competence in globalization, yaitu kemampuan guru yang berkaitan dengan berbagai permasalahbudayadanpendidikansertapenyelesaiannya;(d)competencesinfuturestrategies,

yaitukemampuanguruterkaitprediksitentangapayangterjadidimasadepandanstrateginya. Hal ini bisa dilakukan dengan beberapa cara seperti joint lecturer, joint research, joint resources, staff mobility dan rotation; (e) conselor competence, yaitu kemampuan guru untuk memahami permasalahan peserta didik yang bukan hanya terkait masalah materi ajar, akan tetapi juga masalah psikologis.

E-learningmerupakan salah satu dampak dari revolusi industri 4.0 di bidang pendidikan yang harus atau mampu dikuasai oleh guru profesional seperti yang telah dikemukakan di atas. Konsep dasar e-learningsendiri yaitu sebuah pembelajaran yang dilakukan dengan mengandalkan pada sumber-sumber informasi yang tersedia pada M. Mansur \& Rose | 19 
jaringan internet. Dalam e-learningsendiri peranan guru sebagai sumber belajar yang biasanya menyampaikan informasi kepada peserta didik secara bahasa verbal beralih menjadi orang yang mempunyai fungsi mangarahkan dan memberi petunjuk bagaimana seharusnyapesertadidikbelajarmenambahpengetahuansesuaidengangayabelajarpeserta didik (Sanjaya \& Budimanjaya,2017).

Menurut Sanjaya \& Budimanjaya (2017) terdapat beberapa ciri dari e-learningantara lain: (a) dalam e-learningpeserta didik tidak lagi memerlukan tempat dan waktu khusus untuk belajar, namun peserta didik dapat belajar tanpa terbatas tempat (dimanapun) dan waktu (kapanpun) sesuai dengan kesempatan yang dimiliki oleh masing-masing peserta didik; (b) dalam proses pembelajaran, sumber belajar yang dapat diakses oleh peserta didik tidak hanya terbatas pada sumber cetak berupa buku teks dan lainnya, namun juga sumber belajar yang bersifat digital yang dapat diakses melalui internet; (c) kualitas pembelajaran antara peserta didik dan guru meningkat dengan mengakses informasi dari kesatuan sumber-sumber (data base, perpustakaan, kelompok minat khusus), berkomunikasi via komputer baik dengan peserta didik maupun dengan ahli di bidang pembelajaran masingmasing; (d) guru dan peserta didik dapat mengakses dokumen elektronik untuk memperkaya pembelajaran dan pengetahuan mereka. Peserta didik juga bisa lebih aktif karena e-learningmemberikan lingkungan pembelajaran yang interaktif; dan (e) elearningmemungkinkan guru terpisah secara geografis dari peserta didik dan peserta didik dapat belajar dengan peserta didik lain di ruangan kelas di seluruh dunia. Sedangkan menurut Rusman (2011) e-learningmemiliki karakteristik, antara lain (a) interactivity (interaktivitas);

(b)independency(kemandirian);(c)accessibility(aksesibilitas);dan(d)enrichment(pengayaan).

Hasil penelitian dari Suarsana (2013) yang berjudul "Pengembangan E-modul yang berorientasi pemecahan masalah untuk meningkatkan ketrampilan berfikir kritis mahasiswa" menunjukkan bahwa: (a) E-modul yang telah disusun berkualitas baik, namun masih perlu disempurnakan lagi; (b) penggunaan e-modul dapat meningkatkan keterampilan berpikir kritis mahasiswa; dan (c) tanggapan mahasiswa terhadap penggunaan e-modul dalam perkuliahan adalah sangat positif. Hasil penelitian yang lain dari Ainiyah dan Puspasari (2015) yang berjudul "Penggunaan Edmodo Sebagai Media Pembelajaran ElearningPada Mata Pelajaran Otomatisasi Perkantoran Di SMKN 1 Surabaya" juga menunjukkan keunggulan Edmodo sebagai media pembelajaran yaitu untuk kelas X APK 5 dimanfaatkan sebagai kelas pelengkap, siswa kelas X APK 5 dapat menerima dengan baik 20 | Implementasi Pelatihan Edmodo... 
penggunaan Edmodo sebagai media pembelajaran e-learning, guru juga sangat terbantu dengan adanya Edmodo, sebagai media pembelajaran e-learning Edmodo memiliki banyak kelebihan terutama dari segi fitur-fitur yang ditawarkan, dan kekurangan dari penggunaan Edmodo sebagai media pembelajaran e-learning sangat bergantung dengan jaringaninternet.

SMP Muhammadiyah 1 Kota Malang yang merupakan salah satu sekolah swasta di Kota Malang yang memiliki beberapa keuanggulan diantaranya: pertama, memiliki letak strategis.SMPMuhammadiyah1KotaMalangberlokasidiJalanBrigjenSlametRiadiNo134 Kota Malang. Lokasi ini sangat stretegis karena berada di dekat jantung Kota Malang. Akses yang mudah yaitu bisa ditempuh dengan kendaraan pribadi maupun kendaraan umum. Kedua, prestasi akademik dan non akademik baik di tingkat kota maupun provinsi. Ketiga, heterogenitas latar belakang peserta didik. Hal ini merupakan sebuah keunggulan dan tantangan tersendiri bagi SMP Muhammadiyah 1 Kota Malang karena dengan heterogenitas latar belakang tersebut mengundang segenap stakeholder untuk bekerja keras demi keunggulan SMP Muhammadiyah 1 Malang. Keempat, guru di SMP Muhammadiyah 1 Malang berlatar belakang pendidikan S1 sebanyak $84 \%$ sedangkan yang berpendidikan S2 sebanyak 16\%. kelima, keunggulan lain dari sisi input, fasilitas pendidikan yang dimiliki cukupmemadai.

Hal yang mendasari tim pengabdian kepada masyarakat bermitra dengan SMP Muhammadiyah 1 Kota Malang yaitu adanya keselarasan visi misi dari SMP Muhammadiyah 1 Kota Malang dan tujuan dari tim pengabdian kepada masyarakat. SMP Muhammadiyah 1 Kota Malang dalam menerapkan atau mengimplementasikan elearningmasih terkendala oleh kompetensi sumber daya manusia (SDM) padahal secara sarana dan prasarana sudah memadai, oleh karena itu tim pengabdian kepada masyarakat memberikan pelatihan dan pendampingan e-learningkepada guru-guru di SMP Muhammadiyah 1 Kota Malang.

\section{Metode}

Kegiatan Pengabdian Kepada Masyarakat dilakukan di SMP Muhammadiyah 1 Kota Malang yang berlokasi di Jalan Brigjend Slamet Riyadi No 134 Oro-oro Dowo Kecamatan Klojen Kota Malang Jawa Timur. Peserta pelatihan dan pendampingan e-learningmerupakan semua guru di SMP Muhammadiyah 1 Kota Malang yang berjumlah 23 orang dari berbagai bidang studi. Alasan pemilihan SMP Muhammadiyah 1 Kota Malang dijadikan mitra dalam kegiatan pengabdian kepada masyarakat karena sesuai dengan permasalahan yang dihadapi 
oleh SMP Muhammadiyah 1 Kota Malang. SMP Muhammadiyah 1 Kota Malang telah berencana untuk mengimplementasikan e-learningnamun terkendala adanya kompetensi guru yang belum menguasai penggaplikasian e-learningdalam proses belajar mengajar di sekolah.

Partisipasi SMP Muhammadiyah 1 Kota Malang sebagai mitra dalam kegiatan pengabdian kelompok ini antara lain: (a) persetujuan yang diberikan oleh kepala sekolah untuk melakukan pelatihan e-learning; (b) menyediakan baik sarana dan prasarana yang mendukungpelatihandanpendampingane-learning;(c)kesediaanbeberapaguruyangakan mengikuti dan mengimplementasikan e-learning; (d) sekolah mengimplementasikan elearningpada pembelajaran semester ganjil tahun pelajaran2019/2020.

Kegiatan pengabdian kepada masyarakat ini menggunakan metode pelatihan dan pendampingan e-learningyang dilakukan di SMP Muhammadiyah 1 Kota Malang. Kegiatan Pelatihan dan Pendampingan dilakukan kurang lebih selama 8 bulan, mulai bulan Maret 2019 - Oktober 2019. Beberapa langkah-langkah yang dilakukan dalam kegiatan ini antara lain:

1. Mengadakan kegiatan Focus Group Discussion (FGD).

Kegiatan FGD dilakukan oleh tim pengabdian dengan mitra untuk merancang kegiatan yang akan dilaksanakan dalam waktu 8 bulan. Dalam tahap ini terjadi kesepakatan terkait pembagian tugas pada masing-masing pihak yaitu, tim pengabdian dan guru yang akan mendapatkan pelatihan e-learning.

2. Pelatihan e-learningpada guru-guru di SMP Muhammadiyah 1 KotaMalang.

Kegiatan pelatihan e-learningdikemas dalam bentuk workshop. Selain pemateri menjelaskan secara teoritis terkait e-learningpara peserta yaitu guru-guru juga mempraktikkan e-learning.

3. Pendampingane-learningpada guru-guru di SMP Muhammadiyah 1 Kota Malang. Pendampingan e-learningdilakukan agar guru-guru di SMP Muhammadiyah 1 Malang optimal dalam memahami teori dan mempraktikkan secara lancare-learning.

4. Implementasi e-learning

Setelah tahap pendampingan, maka guru mengimplementasikan e-learning. Implementasi e-learningrencananya akan dilakukan mulai pembelajaran semester ganjil tahun pelajaran 2019/2020.

Terkait kegiatan pelatihan tim melakukan kegiatan selama dua hari dengan total durasi waktu yang dibutuhkan 36 JP. Untuk memperjelas maka akan jabarkan dalam tabel 1 22 | Implementasi Pelatihan Edmodo... 
terkait alokasi waktu kegiatan pelatihane-learning.

Tabel 1. Alokasi Waktu dan Materi Kegiatan Pelatihan

\begin{tabular}{cllc}
\hline No & \multicolumn{1}{c}{ Materi Pelatihan } & \multicolumn{1}{c}{ Narasumber } & Alokasi Waktu \\
\hline 1 & PembelajaranAbad21 & Drs. M. Mansur,M.H & 2 \\
\hline 2 & KompetensiGuruProfesional & $\begin{array}{l}\text { Moh. Wahyu } \\
\text { Kurniawan,S.Pd.,M.Pd }\end{array}$ & 2 \\
\hline 3 & $\begin{array}{l}\text { Dampak Revolusi Industri 4.0 } \\
\text { Dalam BerbagaiBidang }\end{array}$ & Arif PrasetyoWibowo,M,Pd & 2 \\
\hline 4 & $\begin{array}{l}\text { ImplementasiE-learningDalam } \\
\text { Pendidikan }\end{array}$ & Rose FitriaLutfiana,M.Pd & 2 \\
\hline 5 & WorkshopE-learning & Tim Pengabdian & 28 \\
\hline & & Jumlah & 36 \\
\hline
\end{tabular}

\section{Hasil dan Pembahasan}

Mitra Kegiatan Pengabdian Kepada Masyarakat ini adalah SMP Muhammadiyah 1 KotaMalangyangberalamatdiJl.BrigjendSlametRiadiNo.134,Oro-oroDowo,Kec.Klojen, KotaMalang,JawaTimur65119.Tujuandarikegiatanpelatihandanpendampingane-leaning diSMPMuhammadiyah1KotaMalangyaitumembantuguru-gurudiSMPMuhammadiyah 1 Kota Malang untuk meningkatkan kompetensi profesionalnya selain itu juga ikut mendukung program sekolah yang ingin mengimplementasikan e-learningsesuai dengan tuntutan pembelajaran Abad 21 maupun revolusi industri 4.0 dalam bidang pendidikan.

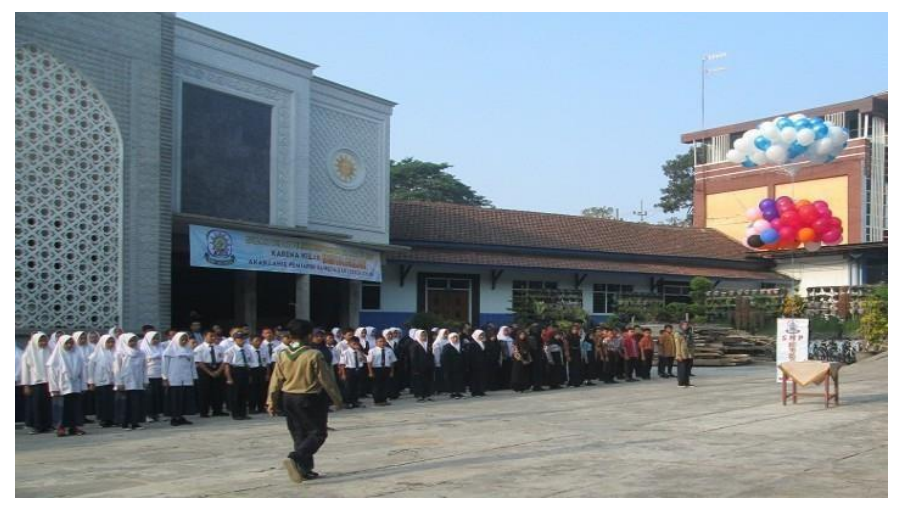

\section{Gambar 1. Gedung SMP Muhammadiyah 1 Kota Malang}

Di kota Malang, SMP Muhammadiyah 1 Kota Malang merupakan salah satu sekolah swasta yang diperhitungkan eksistensinya. SMP Muhammadiyah 1 Kota Malang memiliki lahan seluas $2.535 \mathrm{~m} 2$. Letak sekolah sangat strategis karena berada di pusat kota. Hal ini tentu merupakan sebuah keuntungan karena mudah diakses oleh kendaraan, baik itu kendaraan pribadi maupun kendaraan umum. 


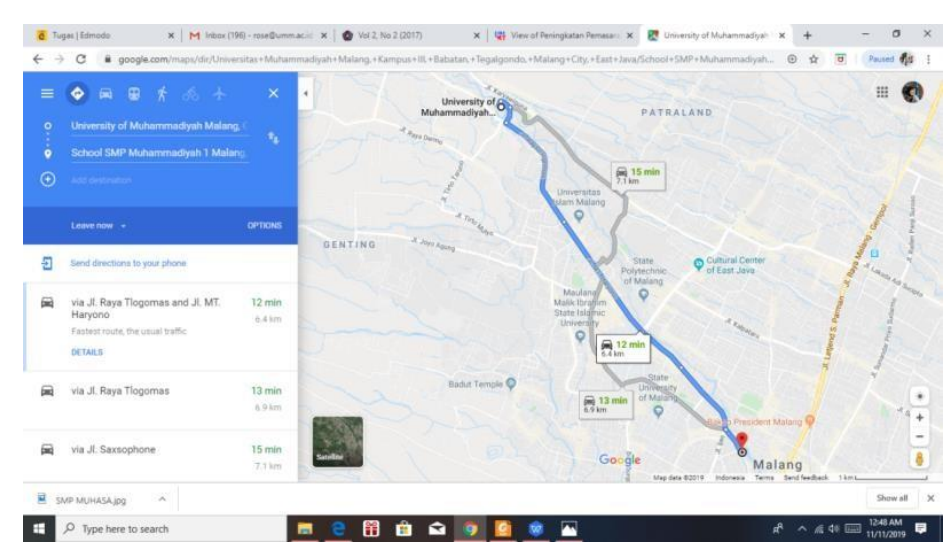

Gambar 2. Peta lokasi SMP Muhammadiyah 1 Kota Malang

SMP Muhammadiyah 1 Kota Malang memiliki visi “terbentuknya manusia bertakwa, terampil berkarya, berwawasan". Sedangkan misinya antara lain: (a) menumbuhkan sikap penghayatan pengalaman ajaran agama dalam kehidupansehari-hari;(b) melaksanakan pembelajaran dan bimbingan secara efektif, inovatif, dan kreatif; (c) menumbuhkan rasa cinta seni dan budaya sehingga siswa mampu berapresiasi dalam bidang seni dan budaya; (d) melatih siswa dengan ketrampilan sebagai bekal untuk menyongsong kehidupan di masa depan; (e) melatih dan meningkatkan segi keagamaan melalui berbagai lomba-lomba; dan (d) menumbuhkan semangat keunggulan dengan pemberdayaan warga sekolah.

Sasaran kegiatan pengabdian kepada masyarakat ini adalah semua guru di SMP Muhammadiyah 1 Kota Malang yang berjumlah 23 orang dari berbagai bidang studi. Tujuannya yaitu meningkatkan kompetensi profesional mereka. Hal ini dikarenakan sesuai dengan tuntutan pembelajaran abad 21 dan juga imbas dari revolusi industri 4.0 di bidang pendidikan.SelainituSMPMuhammadiyah1KotaMalangsecarasaranadanprasaranajuga sudah siap untuk menerapkan e-learning, namun masih terkendalam sumber daya manusia (guru) yang belum memahamie-learning.

Output atau capaian yang dihasilkan dari kegiatan pengabdian kepada masyarakat ini yaitu mengimplementasikan e-learningdi tahun pelajaran 2019/2020. Dari total 23 guru yang ada di SMP Muhammadiyah 1 Kota Malang sebanyak 78,2 \% telah memahami elearning, sedangkan yang telah mengimplementasikannya sebanyak 65,2\%. Berikut ini akan disajikan dalam bentuk tabel 2 untukmemperjelasnya.

\section{Tabel 2. Implementasi e-learning}

\begin{tabular}{cllcc}
\hline No & \multicolumn{1}{c}{ Nama } & \multicolumn{1}{c}{ Mata Pelajaran } & Kelas & Ketarangan \\
\hline 1 & Drs. Budiyono & Bahasa Jawa & IX A,B,C & Sudah \\
\hline 2 & Drs. Muhtar & PPKn & IX A,B & Belum \\
\hline 3 & NurulHidayati, & Bahasa Inggris & VIII A,B & Belum \\
\hline
\end{tabular}

24 | Implementasi Pelatihan Edmodo... 


\begin{tabular}{|c|c|c|c|c|}
\hline & S.Pd & & & \\
\hline \multirow[t]{2}{*}{4} & Dra.TriSulawesining & IPS & VIII A,B & Belum \\
\hline & $\operatorname{sih}$ & & IX A,B,C & \\
\hline \multirow[t]{2}{*}{5} & Drs. M. Ibrahim & Kemuhammadiyahan & VII A & Belum \\
\hline & & & VIII A,B & \\
\hline 6 & Lestiana, S.Pd & Prakarya & VII A & Sudah \\
\hline 7 & Pudjijanto, S.Ag & PAI & IX A,B,C & Sudah \\
\hline \multirow[t]{2}{*}{8} & Masrudi, S.Pd & IPA & VIII A,B & Sudah \\
\hline & & & IX C & \\
\hline 9 & Taufiqurrahman,S.S & Bahasa Inggris & & Belum \\
\hline \multirow[t]{3}{*}{10} & Sarbini & Seni Budaya & VII A & Sudah \\
\hline & Kuswantoro,SP.,M.P & & VIII A,B & \\
\hline & $\mathrm{d}$ & & IX A,B,C & \\
\hline \multirow[t]{2}{*}{11} & Solikhul Atmam, & $\mathrm{BP}$ & VII A & Sudah \\
\hline & S.PdI & & VIII A,B & \\
\hline \multirow[t]{3}{*}{12} & Ahmad Rusydani, & PJOK & VII A & Belum \\
\hline & S.Pd & & VIII A,B & \\
\hline & & & IX A,B,C & \\
\hline \multirow[t]{2}{*}{13} & Yanur & IPA & VII A & Sudah \\
\hline & Setyaningrum, M.Pd & & IX A,B & \\
\hline 14 & Mawaddah, S.Pd & Bahasa Indonesia & IX A,B,C & Sudah \\
\hline \multirow[t]{2}{*}{15} & Farida Ulfa & Matematika & VIII B & Sudah \\
\hline & $\begin{array}{l}\text { Nurhidayati, S.Si., } \\
\text { M.Pd }\end{array}$ & & IX A,B,C & \\
\hline 16 & Aris Andrianta, S.Pd & BK & & Belum \\
\hline \multirow[t]{2}{*}{17} & Yuli & PPKn & VIII A & Sudah \\
\hline & $\begin{array}{l}\text { Wachyuningtyas, } \\
\text { S.Pd }\end{array}$ & & IX C & \\
\hline 18 & $\begin{array}{l}\text { Rachmad Hidayat, } \\
\text { S.Pd }\end{array}$ & IPS & & Belum \\
\hline \multirow[t]{2}{*}{19} & Dini Ramadhani, & Bahsa Indonesia & VII A & Sudah \\
\hline & S.Pd & & VIII A,B & \\
\hline \multirow[t]{2}{*}{20} & Nosa Setiabudi, S.Pd & Bahasa Inggris & VII A & Sudah \\
\hline & & & IX $A, B, C$ & \\
\hline \multirow[t]{2}{*}{21} & Vini Anggraeni & IPS & VII A & Sudah \\
\hline & Niki Laoda, S.Pd & & VIII A,B & \\
\hline \multirow[t]{2}{*}{22} & Helni Zehniar, M.Pd & Matematika & VII A & Sudah \\
\hline & & & VIII A & \\
\hline \multirow[t]{2}{*}{23} & Artari Febrianti, & PPKn & VII A & Sudah \\
\hline & S.Pd & & VIII B & \\
\hline
\end{tabular}

\section{Simpulan}

Kegiatan pelatihan e-learningbertujuan untuk meningkatkan kompetensi profesional guru di SMP Muhammadiyah 1 Kota Malang. Sasaran dari kegiatan ini adalah semua guru 
yang ada di SMP Muhammadiyah 1 Kota Malang yang berjumlah 23 orang. SMP Muhammadiyah 1 Kota Malang dipilih sebagai tempat pengabdian kepada masyarakat karena dalam pengimplementasian e-learningmasih terkendala sumber daya manusia (guru) yang belum memahami e-learning. Kegiatan pelatihan dan pendampingan ini dilakukanmelalui empat tahapan yaitu focus group discussion (FGD), pelatihan, pendampingan dan monitoring evaluasi. Hasil dari kegiatan pengabdian kepada masyarakat ini antara lain: hampir $78,2 \%$ guru yang mengikuti pelatihan dan pendampingan elearningtelah mampu mengguasai e-learningdan hampir 65,2\% guru yang mengikuti kegiatan pengabdian kepada masyarakat ini telah mengimplementasikan e-learningpada pembelajaran semester ganjil 2019/2020.

\section{Daftar Pustaka}

Ainiyah,Zamrotul \& Puspasari, Durinta. 2015. Penggunaan Edmodo Sebagai Media Pembelajaran E-learningPada Mata Pelajaran Otomatisasi Perkantoran Di SMKN 1 Surabaya. Jurnal Administrasi Perkantoran. 3 (3), 1-13

Rusman. 2011. Pembelajaran Berbasis Teknologi Informasi dan Komunikasi: Mengembangkan Profesionalitas Guru. Jakarta: PT. Raja Grafindo.

Sanjaya, Wina \& Budimanjaya, Andi. (2017). Paradigma Baru Mengajar. Jakarta: Kencana.

Suarsana, I.M. 2013. Pengembangan E-modul Yang Berorientasi Pemecahan Masalah Untuk Meningkatkan Ketrampilan Berfikir Kritis Mahasiswa. Jurnal Pendidikan Indonesia. 2 (2), 264-275

Syamsuar \& Raflianto. (2018). Pendidikan dan Tantangan Pembelajaran Berbasis Teknologi Informasi di Era Revolusi Industri 4.0. E-TECH: Jurnal Ilmiah Teknologi Pendidikan. 6 (2), $1-13$.

Wahyuni, Dinar. (2018). Peningkatan Kompetensi Guru Menuju Era Revolusi Industri 4.0.Info Singkat. 10 (24), 13-18. 